\title{
ANALISIS KUALITAS DAN STRATEGI PENGENDALIAN PENCEMARAN AIR KALI SURABAYA
}

\section{QUALITY ANALYSIS AND POLLUTION CONTROL STRATEGY OF SURABAYA RIVER WATER}

\author{
Adi Trisnawati*1 ${ }^{1}$ ), Ali Masduqi ${ }^{2}$ ) \\ ${ }^{1)}$ Program Studi Magister Teknik Lingkungan, ITS \\ ${ }^{2)}$ Jurusan Teknik Lingkungan, ITS \\ *Email: adhie@enviro.its.ac.id
}

\begin{abstract}
Abstrak
Sebagian besar limbah cair hasil dari kegiatan manusia dibuang ke saluran. Sekitar $60 \%$ pencemaran Kali Surabaya berasal dari limbah domestik (Fatnasari dan Hermana, 2010). Padahal air Kali Surabaya memasok sekitar 96\% kebutuhan air baku Perusahaan Daerah Air Minum (PDAM) Kota Surabaya (Herera dkk, 2013). Penelitian ini bertujuan untuk mengidentifikasi tingkat pencemaran dan menentukan prioritas strategi pengendalian pencemaran air Kali Surabaya menggunakan AHP (Analitycal Hierarchy Processes). Pengumpulan data sekunder berupa data kualitas air Kali Surabaya yang terdiri dari temperatur, TSS, pH, BOD, COD, DO, nitrat, amonia, kromium, tembaga, nitrit, minyak, deterjen, fenol, total coli, dan faecal coli yang dibandingkan dengan baku mutu air kelas 2 berdasarkan Peraturan Pemerintah nomor 82 tahun 2001. Kemudian dilakukan penentuan status mutu air Kali Surabaya menggunakan metode indeks pencemaran berdasarkan Keputusan Menteri Lingkungan Hidup Nomor 115 tahun 2003. Analisis Strategi pengendalian pencemaran air Kali Surabaya didapat setelah dilakukan pembagian kuesioner kepada Badan Lingkungan Hidup Provinsi Jawa Timur, Dinas Pekerjaan Umum Pengairan, Perum Jasa Tirta, Dinas Perindustrian dan Perdagangan, PDAM dan Tokoh Masyarakat. Hasil penelitian menunjukkan bahwa parameter pencemar air Kali Surabaya adalah TSS, BOD, DO, nitrit, minyak, dan fenol. Selain itu, status mutu air Kali Surabaya termasuk tercemar ringan. Hasil running prgram AHP diketahui bahwa strategi pengendalian pencemaran air Kali Surabaya lebih menitik beratkan pada ketegasan dalam menaati peraturan perundangan yang berlaku.
\end{abstract}

Kata kunci: AHP, indeks pencemaran, Kali Surabaya, strategi

\begin{abstract}
The Surabaya River's main problem currently was the wastewater resulted from human activities mostly being discharged into the river. About $60 \%$ of Surabaya River pollution originated from domestic wastewater (Fatnasari dan Hermana, 2010). Infact, about 96\% of water Perusahaan Daerah Air Minum (PDAM) Surabaya take from this river (Herera dkk, 2013). This study aims for identification of pollution level and determination of strategy priority of water pollution control in Surabaya River using Analytical Hierarchy Processes (AHP). The study was begun from secondary data collection of water quality parameter of: temperature, TSS, pH, BOD, COD, DO, nitrate, nitrite, ammonia, chromium, copper, oil, detergent, phenol, total coli and faecal coli. The data would be compared with stream standard. Then quality status of Surabaya River water was determined by using pollution index method according to Ministry of Environment Decree NO. 115/2003. The analysis of strategy to control Surabaya River water was done by questionnaire and direct interview methods to Badan Lingkungan Hidup (BLH) of East Java Province, Dinas Pekerjaan Umum Pengairan, Perum Jasa Tirta I, Dinas Perindustrian dan Perdagangan, PDAM and several affectional peoples in society. The result of study shows that the polluting parameters of water in Surabaya River were TSS, BOD, DO, nitrite, oil and phenol. The water quality status of Surabaya River is categorized as low polluted. From the result of AHP the strategy of water pollution control in Surabaya River should be focused on social aspect which more focused firmness in keeping the existing regulations.
\end{abstract}

Keywords: AHP, pollution index, Kali Surabaya, strategy 


\section{PENDAHULUAN}

Sungai memiliki fungsi sebagai sumber air baku untuk pengolahan air bersih, transportasi, irigasi, perikanan, rekreasi, komunikasi, konservasi (ekosistem air sungai), dan lain-lain. Kota Surabaya mempunyai 6 sungai, 27 saluran primer, dan 142 saluran sekunder. Kali Surabaya merupakan sungai terpanjang di Kota Surabaya dengan panjang $17.400 \mathrm{~m}$. Aliran sungai Kota Surabaya dimulai dari DAM Mlirip (Kabupaten Mojokerto) melewati Sidoarjo, Gresik, dan sampai pada DAM Jagir Wonokromo (Surabaya) (SLHD, 2011).

Sekitar 96\% air baku PDAM Kota Surabaya dipasok dari Kali Surabaya. Sedangkan kualitas air Kali Surabaya tidak mendukung sebagai peruntukkan badan air sumber air baku karena beban pencemar Kali Surabaya telah melebihi baku mutu air Kelas II (Herera dkk, 2013). Sementara itu, bila ditinjau dari segi kuantitas, Perum Jasa Tirta telah memprediksi bahwa pada tahun 2025, Surabaya akan mengalami defisit air bersih sebesar 7,43 $\mathrm{m}^{3} /$ detik (Kusumawardani, 2010).

Masalah utama Kali Surabaya adalah sebagian besar limbah cair hasil dari kegiatan manusia dibuang ke saluran yang bermuara di Kali
Surabaya. Limbah tersebut berasal dari pemukiman, industri, pertanian, peternakan, dan lain-lain. Sekitar $60 \%$ pencemaran Kali Surabaya berasal dari limbah domestik (Fatnasari dan Hermana, 2010). Hal yang perlu dikhawatirkan adalah pencemaran oleh limbah industri. Menurut hasil riset Ecoton dan National Institute Minamata Disease menunjukkan bahwa badan air, lumpur, kerang, ikan, dan ekosistem Kali Surabaya telah terkontaminasi merkuri, timbal, kadmium, tembaga, dan besi dengan kadar yang melebihi ambang batas.

Analytic Hierarchy Process (AHP) pertama kali dipresentasikan oleh Saaty (1980) untuk memodelkan proses pengambilan keputusan yang subyektif dengan sistem hirarki. AHP lebih sederhana jika dibandingkan dengan metode pengambilan keputusan yang telah ada sebelumnya (Hwang dan Syamsudin, 2009). AHP merupakan alat pengambilan keputusan multikriteria yang fleksibel dan kuat untuk memecahkan masalah yang kompleks dimana aspek kualitatif dan kuantitatif perlu dipertimbangkan. AHP membantu para analis untuk mengatur aspek kritis dari masalah kedalam suatu struktur yang mirip dengan

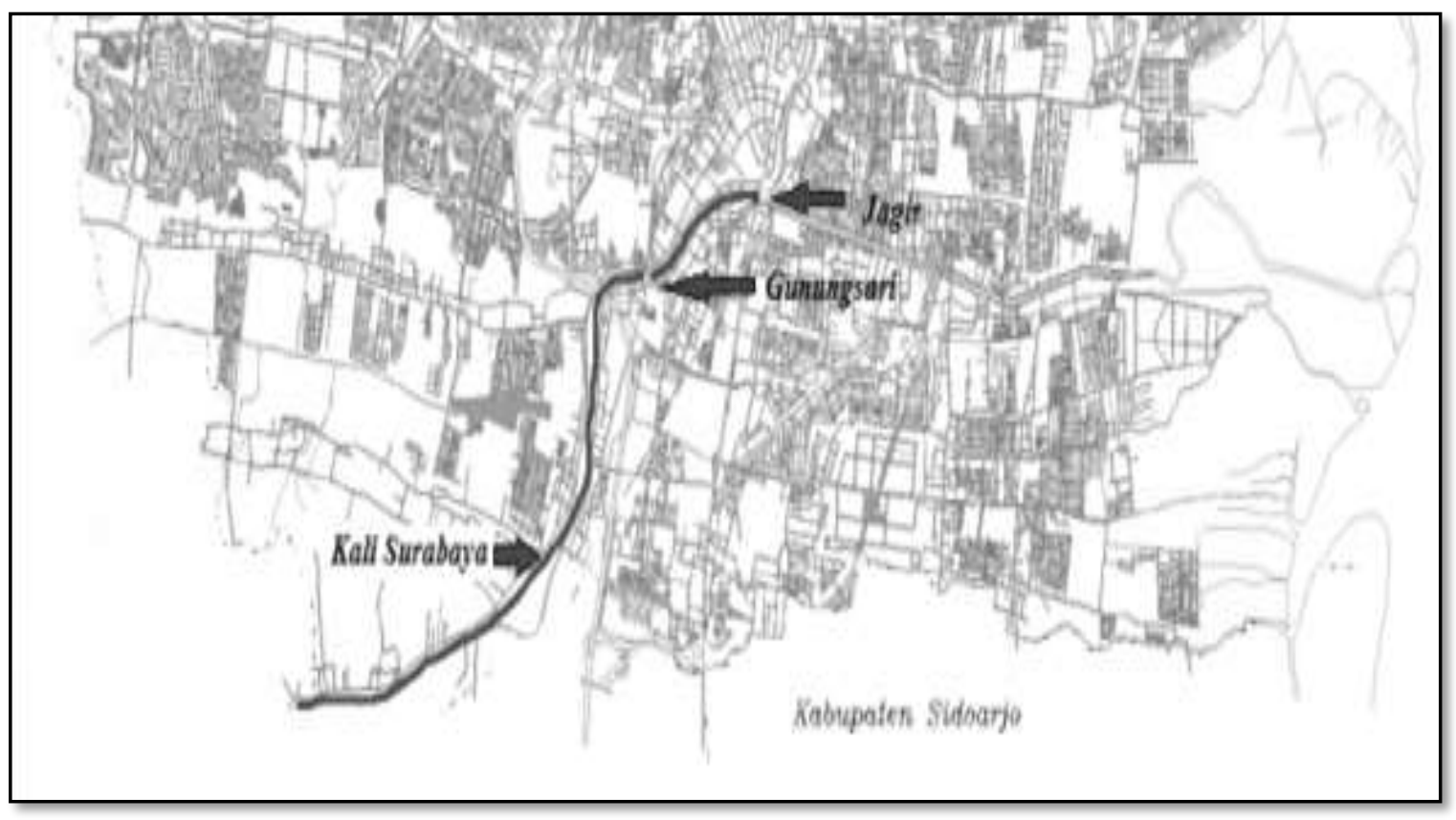

Gambar 1. Lokasi Penelitian Pada Aliran Kali Surabaya 
diagram pohon (Bevilacqua dan Braglia, 2000). Tujuan AHP adalah untuk membuat masalah yng kompleks menjadi tersistem, memberikan tingkat dekomposisi dari perspektif yang berbeda dan melalui metode kuantitatif, mengkontekstualisasikan untuk membuat penilaian yang komprehensif dengan maksud untuk memberikan pengambil keputusan yang tepat (Wang dan Jhen, 2010). Pencemaran pada air merupakan hal yang kompleks karena melibatkan cakupan area sepanjang aliran sungai. Hal ini diperparah dengan lemahnya hukum terhadap kebijakan yang telah dibuat untuk mendukung kualitas dan kuantitas air Kali Surabaya. Penelitian ini bertujuan untuk mengidentifikasi tingkat pencemaran dengan membandingkan data kualitas air Kali Surabaya dengan baku mutu, identifikasi status mutu air dan menentukan prioritas strategi pengendalian pencemaran air Kali Surabaya menggunakan Program AHP (Analitycal Hierarchy Processes). Strategi tersebut didasarkan pada 4 aspek yaitu aspek teknis, aspek sosial, aspek kelembagaan, dan aspek lingkungan.

\section{METODA}

Metode pada penelitian ini adalah metode pengumpulan data dan metode evaluasi. Data yang dikumpulkan berupa data primer dan data sekunder. Pertama kali dilakukan pengumpulan data sekunder berupa data kualitas air Kali Surabaya tahun 2010 hingga 2013 pada titik sampling Gunungsari dan Jagir yang didapat dari Perum Jasa Tirta. Data kualitas tersebut antara lain temperatur, TSS, $\mathrm{pH}, \mathrm{BOD}, \mathrm{COD}$,
DO, nitrat, amonia, kromium, tembaga, nitrit, minyak, deterjen, fenol, bakteri coli/total coli, dan faecal coli. Pengumpulan data primer diperoleh dari wawancara/pembagian kuesioner kepada orang yang ahli dalam bidang pencemaran air atau pengendalian pencemaran air. Orang-orang tersebut berasal dari BLH Privinsi Jawa Timur, Perum Jasa Tirta, Dinas Pekerjaan Umum dan Pengairan Provinsi Jawa Timur, Dinas Perdagangan dan Perindustrian Kota Surabaya, Perusahaan Daerah Air Minum Kota Surabaya, dan Tokoh Masyarakat dari Kelurahan Gunungsari dan Wonokromo.

Metode evaluasi yang dilakukan adalah identifikasi parameter pencemar air Kali Surabaya dengan membandingkan data kualitas air Kali Surabaya dengan baku mutu badan air kelas II berdasarkan Peraturan Pemerintah No. 82 tahun 2001. Kemudian mengidentifikasi status mutu air Kali Surabaya menggunakan metode indeks pencemaran berdasarkan Keputusan Menteri Lingkungan Hidup No. 115 tahun 2003, menggunakan persamaan:

$P I_{j}=\sqrt{\frac{\left(C_{i} / L_{i j}\right)_{M}^{2}+\left(C_{i} / L_{i j}\right)_{R}^{2}}{2}}$

Tabel 1. Hubungan Nilai PI dengan Status Mutu Air

\begin{tabular}{cc}
$\begin{array}{c}\text { Indeks Pencemaran } \\
(\text { IP) }\end{array}$ & Status Mutu \\
\hline $0 \quad \leq \mathrm{PI}_{\mathrm{j}} \leq 1,0$ & Kondisi baik \\
$1,0 \leq \mathrm{PI}_{\mathrm{j}} \leq 5,0$ & Cemar ringan \\
$5,0 \leq \mathrm{PI}_{\mathrm{j}} \leq 10$ & Cemar sedang \\
$\mathrm{PIj} \geq 10$ & Cemar berat \\
\hline
\end{tabular}

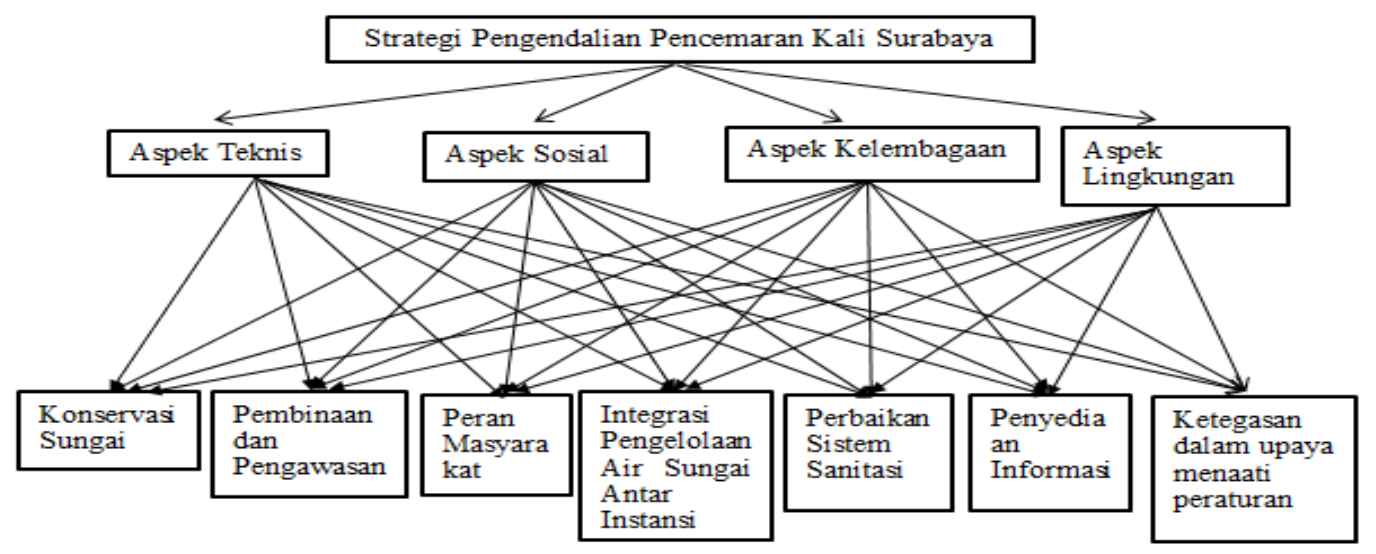

Gambar 2. Lokasi Penelitian Pada Aliran Kali Surabaya di Stasiun Monitoring Gunungsari 
Indeks pencemaran yang diperoleh akan diuji secara statistik menggunakan Uji T dengan nilai signifikan $5 \%$ menggunakan persamaan:

$z_{\text {hit }}=\frac{\bar{x}-\mu_{0}}{\sigma / \sqrt{n}} \ldots \ldots \ldots \ldots \ldots \ldots \ldots \ldots \ldots \ldots \ldots \ldots$

Evaluasi hasil kuesioner dilakukan dengan menggunakan software expert choice. Sebelum data kuesioner diinputkan kedalam program, perlu dilakukan normalisasi data kuesioner yang didapat dengan menggunakan persamaan ratarata ukur berikut :

$a_{w}=\sqrt[n]{a_{1} x a_{2} x \ldots x a_{n}}$

Hasil kuesioner yang sudah dinormalisasi kemudian diinputkan ke program expert choice. Kemudian model dapat dirunning. Hasil running dikatakan valid jika nilai inconsistency $\leq 10 \%$. Hal ini untuk menghindari ketidakkonsistenan dari jawaban para ahli. Jika nilai inconsistency $\geq 10 \%$, maka dilakukan pengisian kuesioner ulang.

\section{HASIL DAN PEMBAHASAN}

Hasil dan pembahasan dilakukan melalui tiga tahap yaitu identifikasi kualitas air Kali Surabaya sehingga diketahui parameter penyebab pencemaran air sungai. Kemudian ditentukan tingkat pencemaran yang terjadi dengan menggunakan indeks pencemaran. Kedua analisis tersebut digunakan sebagai landasan para ahli dalam pemilihan prioritas pada kuesioner.

\section{Analisis Kualitas Air Kali Surabaya}

Temperatur air sungai dipengaruhi oleh suhu udara sekitar sehingga patokan yang digunakan pada baku mutu adalah suhu udara normal. Suhu udara normal adalah $28^{\circ} \mathrm{C}$. Baku mutu temperatur air sungai kelas II menurut PP 82/2001 menyatakan bahwa temperatur air sungai berada pada deviasi 3 yang artinya suhu air sungai berada pada kisaran suhu udara normal $\pm 3^{\circ} \mathrm{C}$ atau berada antara $25^{\circ} \mathrm{C}-31^{\circ} \mathrm{C}$. Menurut data stasiun monitoring Gunungsari, rata-rata temperatur air Kali Surabaya masih memenuhi baku mutu air sungai kecuali pada
Bulan Februari 2010, Januari 2012, dan Februari 2012. Sedangkan temperatur air Kali Surabaya di Jagir yang melebihi baku mutu berada pada Bulan September 2010, Oktober 2012, dan November 2012. Pada awal dan akhir tahun terjadi peningkatan suhu karena musim kemarau.

Total Suspended Solid (TSS) adalah salah satu parameter yang mencemari air Kali Surabaya di titik Gunungsari dan Jagir karena keberadaannya di air Kali Surabaya telah melebihi baku mutu dari tahun ke tahun. Kandungan TSS tertinggi di air Kali Surabaya pada Bulan Desember 2012 yaitu sebesar 1000 mg/L di Gunungsari dan 1290 mg/L di Jagir.

Berdasarkan data yang ada, pH air Kali Surabaya di titik Gunungsari dan Jagir tahun 2010-2013 tergolong stabil karena berada pada rentang $6-9$ bahkan tidak melebihi 8 .

Seperti TSS, Biochemical Oxygen Demand (BOD) adalah salah satu parameter yang mencemari air Kali Surabaya. Hal ini dapat dibuktikan dari trend BOD di air Kali Surabaya dari tahun ke tahun telah melebihi baku mutu. BOD tertinggi terjadi pada Bulan Juni 2012 yaitu $11,94 \mathrm{mg} / \mathrm{L}$ di titik Gunungsari dan 10,83 mg/L di titik Jagir. Beda dari BOD, chemical oxygen demand (COD) air Kali Surabaya ratarata masih dibawah baku mutu yaitu $17,38 \mathrm{mg} / \mathrm{L}$ di stasiun monitoring Gunungsari dan 19,81 $\mathrm{mg} / \mathrm{L}$ di stasiun monitoring Jagir.

Dissolved Oxygen (DO) merupakan kandungan oksigen dalam air sehingga jika hasil pengukuran lebih kecil dari baku mutu maka dapat dikatakan air tersebut tercemar. Baku mutu DO air sungai kelas II minimum adalah 4 mg/L. Data DO air Kali Surabayamenunjukkan bahwa kandungan oksigen terlarut air Kali Surabaya tidak memenuhi baku mutu sungai kelas 2. Rata-rata kandungan DO air Kali Surabaya di stasiun monitoring Gunungsari dari tahun 2010 hingga 2013 yaitu 3,53 mg/L sedangkan di stasiun monitoring Jagir yaitu 3,42 $\mathrm{mg} / \mathrm{L}$. Sedangkan kandungan nitrat $\left(\mathrm{NO}_{3}-\mathrm{N}\right)$ air Kali Surabaya di titik Gunungsari dan Jagir tahun 2010-2013 masih dibawah baku mutu. 
Rata-rata kandungan amonia $\left(\mathrm{NH}_{3}-\mathrm{N}\right)$ di air Kali Surabaya di titik Gunungsari dan Jagir tahun 2010-2013 masih dibawah baku mutu yaitu $0,17 \mathrm{mg} / \mathrm{L}$ di stasiun monitoring Gunungsari dan $0,25 \mathrm{mg} / \mathrm{L}$ di stasiun monitoring Jagir. Selain itu, kandungan kromium air Kali Surabaya rata-rata masih dibawah baku mutu. Tetapi perlu diperhatikan dibeberapa bulan telah terdeteksi kandungan kromium yang melebihi baku mutu baik di stasiun monitoring Gunungsari maupun Jagir. Kandungan kromium tertinggi terdeteksi di stasiun monitoring Gunungsari sebesar 0,41 $\mathrm{mg} / \mathrm{L}$ pada Oktober 2010 dan $0,35 \mathrm{mg} / \mathrm{L}$ pada April 2013. Sedangkan kandungan kromium tertinggi di stasiun monitoring Jagir adalah 0,45 mg/L pada Februari 2012.

Kandungan tembaga air Kali Surabaya rata-rata masih dibawah baku mutu. Dari grafik terlihat bahwa terdapat pencemaran air sungai oleh tembaga pada Bulan Januari 2011 sebesar 0,023 $\mathrm{mg} / \mathrm{L}$ dan Bulan Juli 2012 sebesar 0,022 mg/L. Kandungan nitrit $\left(\mathrm{NO}_{2}-\mathrm{N}\right)$ air Kali Surabaya di Titik Gunungsari dan Jagir tahun 2010-2013 sudah melebihi baku mutu peruntukan air sungai kelas II. Pencemaran tertinggi terjadi pada Bulan September 2011 sebesar 1,64 mg/L.

Salah satu parameter kimia organik yang dianalisis pada penelitian ini adalah minyak. Data menunjukkan bahwa minyak merupakan penyumbang pencemaran air Kali Surabaya karena rata-rata kandungan minyak di stasiun monitoring Gunungsari dan Jagir selama 20102013 telah melebihi baku mutu. Rata-rata kandungan minyak di titk Gunungsari adalah 1,3 mg/L, sedangkan di Jagir adalah 1,44 mg/L. Data kandungan deterjen air Kali Surabaya menyatakan bahwa deterjen bukan salah satu penyebab pencemaran air sungai karena keberadaan deterjen dalam air Kali Surabaya di Titik Gunungsari dan Jagir pada tahun 20102013 masih dibawah baku mutu peruntukan air sungai kelas II. Selain minyak, parameter kimia organik yang patut diwaspadai saat ini adalah fenol karena menurut data kualitas air Kali Surabaya di stasiun monitoring Gunungsari dan Jagir tahun 2010-2013 menunjukkan bahwa kandungan fenol telah melampaui baku mutu peruntukan air sungai kelas II.

Baku mutu parameter mikrobiologi total coliform menurut PP 82/2001 adalah 5000/100 $\mathrm{mL}$. Data total coliform menunjukkan bahwa total coliform bukan termasuk pencemar air Kali Surabaya meskipun ada beberapa data yang menunujukkan bahwa total coliform melampaui baku mutu. Selain total coliform, parameter mikrobiologi lain yaitu faecal coliform. Data faecal coliform menunjukkan bahwa faecal coliform bukan termasuk pencemar air Kali Surabaya meskipun ada beberapa data yang menunujukkan bahwa parameter ini melampaui baku mutu.

\section{Status Mutu Air Kali Surabaya}

Status mutu air Kali Surabaya (Tabel 4.3) ditentukan dari data kualitas yang ada menggunakan rumus indeks pencemaran berdasarkan Keputusan Menteri Negara Lingkungan Hidup No 115 Tahun 2003. Indeks Pencemaran dihitung berdasarkan rumus (1).

$P I_{j}=\sqrt{\frac{\left(C_{i} / L_{i j}\right)_{M}^{2}+\left(C_{i} / L_{i j}\right)_{R}^{2}}{2}}$

1. Ci diambil dari hasil pengukuran tiap bulan. Jika ada lebih dari satu data maka diambil nilai rata-rata setiap masing-masing parameter yang diuji.

2. Menghitung nilai $\mathrm{Ci} / \mathrm{Lix}$ dan $\mathrm{Ci} / \mathrm{Lix}$ baru: Baku mutu Air TSS (Lix) yaitu $50 \mathrm{mg} / \mathrm{L}$ (sesuai PP. RI no.82 tahun 2001)

Nilai mutu air rata-rata TSS $\left(\mathrm{Ci}_{\text {rata-rata }}\right)=102,9$ $\mathrm{mg} / \mathrm{L}$ (Gunungsari, Januari 2010). Nilai Ci/Lix $=102,9 / 50=2,058$. Karena nilai $\mathrm{Ci} / \mathrm{Lix}>1$, maka menggunakan nilai $\mathrm{Ci} / \mathrm{Lix}$ baru.

$$
\begin{aligned}
(\mathrm{Ci} / \mathrm{Lij}) \text { baru } & =1,0+\mathrm{P} \cdot \log (\mathrm{Ci} / \mathrm{Lij}) \\
\text { Hasil pengukuran } & =1,0+5 \cdot \log (2,058) \\
& =2,567
\end{aligned}
$$

Baku mutu COD (Lix) yaitu $25 \mathrm{mg} / \mathrm{l}$. (sesuai PP. RI no. 82 tahun 2001). Nilai mutu air ratarata $\mathrm{COD}\left(\mathrm{Ci}_{\text {rata-rata }}\right)=12,4 \mathrm{mg} / \mathrm{L}$ (Gunungsari, 
Januari 2010). Nilai Ci/Lix $=12,4 / 25=0,133$. Karena nilai $\mathrm{Ci} / \mathrm{Lix}<1$, maka tidak perlu dicari nilai $\mathrm{Ci} / \mathrm{Lix}$ baru.

Jika nilai konsentrasi parameter yang menurun menyatakan tingkat pencemaran meningkat, misal DO. Menentukan nilai teoritik atau nilai maksimum $\mathrm{Cm}$ (misal untuk DO, maka $\mathrm{Cm}$ merupakan nilai DO jenuh). Dalam kasus ini nilai hasil pengukuran digantikan oleh nilai $\mathrm{Ci} /$ Lij hasil perhitungan, yaitu :

$$
\begin{aligned}
& \left.\left(\frac{C i}{\text { Lij }}\right)_{\text {baru }} \text { Ci hasil pengukuran }\right) \\
& =\frac{\left(C_{M}-. .\right.}{\left(C_{M}-\text { Lij }\right)}
\end{aligned}
$$

Baku mutu Air DO untuk kelas 2 (Lix) yaitu 4 mg/l (sesuai PP RI no. 82 tahun 2001). Nilai mutu air rata-rata $\mathrm{DO}(\mathrm{Ci}$ rata-rata $)=3,3$ (Gunungsari, Januari 2010). DO jenuh $=\mathrm{CM}=$ 7 (pada suhu $25^{\circ} \mathrm{C}$, di anggap sama pada semua kondisi).

$$
(\mathrm{Ci} / \mathrm{Lij})_{\mathrm{baru}}=\frac{(7-3,3)}{(7-6)}=1,233
$$

Karena nilai $\mathrm{Ci} /$ Lix $>1$, maka menggunakan nilai Ci/Lix baru.

$(\mathrm{Ci} / \mathrm{Lij})$ baru $=1,0+\mathrm{P} \cdot \log (\mathrm{Ci} / \mathrm{Lij})$ hasil

Pengukuran $=1,0+5 \cdot \log (1,233)$

$$
=1,455
$$

Jika nilai baku Lij memiliki rentang.

Untuk $\mathrm{Ci}<$ Lij rata-rata :

$$
(C i / L i j)_{\text {baru }}=\frac{(C i-L j \text { rata }- \text { rata })}{\{(L j) \min -(L j) \text { rata }- \text { rata }\}}
$$

Untuk $\mathrm{Ci}>$ Lij rata-rata :

$$
\begin{aligned}
& (C i / L i j)_{\text {baru }} \\
& =\frac{(C i-L j \text { rata }- \text { rata })}{\{(L j) \text { max }-(\text { Lj }) \text { rata }- \text { rata }\}} \ldots
\end{aligned}
$$

Baku mutu Air pH untuk air minum (Lix) yaitu 6-9 mg/l (sesuai PP. RI no.82 tahun
2001). Nilai mutu air rata-rata $\mathrm{pH}\left(\mathrm{Ci}_{\text {rata-rata }}\right)$ $=7,3$ (Gunungsari, Januari 2010)

$$
\text { Lix rata }- \text { rata }=\frac{6+9}{2}=7,5
$$

Jadi, $\mathrm{Ci}<$ Lix rata-rata maka menggunakan rumus:

$$
(C i / L i j)_{b a r u}=\frac{7,3-7,5}{6-7,5}=0,133
$$

Lakukan hal yang sama untuk tiap-tiap parameter sesuai dengan ketentuan-ketentuan di atas.

3. Menghitung nilai rata-rata $\left((\mathrm{Ci} / \mathrm{Li})_{\mathrm{R}}\right)$ dan nilai maksimum $\left.(\mathrm{Ci} / \mathrm{Lij})_{\mathrm{M}}\right)$ dari keseluruhan $\mathrm{Ci} / \mathrm{Lij}$ baru.

$$
\text { Pada contoh ini nilai nilai rata-rata }
$$
$\left((\mathrm{Ci} / \mathrm{Li})_{\mathrm{R}}\right)=1,663$ dan nilai $\left.(\mathrm{Ci} / \mathrm{Lij})_{\mathrm{M}}\right)=$ 8,955 (Perhitungan Gunungsari Bulan Januari 2010)

4. Menghitung harga Pij

$$
\begin{gathered}
P I j=\sqrt{\frac{\left\{(C i / L i j)^{2}{ }_{R,}+(C i / L i j)^{2}\right\}}{2}} \\
P I j=\sqrt{\frac{\left\{(1,663)^{2}+(8,995)^{2}\right.}{2}}=6,441
\end{gathered}
$$

Menentukan status mutu air sesuai evaluasi terhadap nilai PI. Pada contoh ini nilai PIj adalah 6,441, ini berarati pada stasiun monitoring bendungan Gunungsari Bulan Januari tahun 2010 mempunyai mutu air Tercemar Sedang untuk peruntukan bahan baku air minum. Tabel 2 Menunjukkan Penentuan Status Mutu Air Kali Surabaya di Titik Gunungsari Bulan Januari 2010. Penentuan status mutu air Kali Surabaya selengkapnya dapat dilihat pada Tabel 2 dan 3. Hasil perhitungan status mutu air Kali Surabaya pada stasiun monitoring Gunungsari dan Jagir menunjukkan bahwa kondisi air sungai saat ini tercemar ringan. Oleh karena status mutu air Kali Surabaya di titik Gunungsari dan Jagir adalah tercemar ringan dan sedang, maka perlu dilakukan uji statistik diharapkan adalah 5\% yang artinya nilai $\mathrm{z}_{0,05}=1,645$. Berdasarkan rekapitulasi status mutu dengan menggunakan metode indeks pencemaran (Tabel 2 dan 3). 
Tabel 2. Rekapitulasi Status Mutu Air Kali Surabay di Stasiun Monitoring Gunungsari

\begin{tabular}{|c|c|c|c|c|c|c|c|c|}
\hline \multirow{2}{*}{ Bulan } & \multicolumn{2}{|r|}{2010} & \multicolumn{2}{|r|}{2011} & \multicolumn{2}{|r|}{2012} & \multicolumn{2}{|r|}{2013} \\
\hline & IP & Status mutu air & IP & Status mutu air & IP & Status mutu air & IP & Status mutu air \\
\hline Jan & 6.441 & tercemar sedang & 4.740 & tercemar ringan & 3.816 & tercemar ringan & 2.883 & tercemar ringan \\
\hline Feb & 4.678 & tercemar ringan & 1.861 & tercemar ringan & 1.131 & tercemar ringan & 3.260 & tercemar ringan \\
\hline Mar & 6.340 & tercemar sedang & 2.497 & tercemar ringan & 2.839 & tercemar ringan & 2.823 & tercemar ringan \\
\hline Apr & 1.893 & tercemar ringan & 5.660 & tercemar sedang & 2.034 & tercemar ringan & 4.434 & tercemar ringan \\
\hline Mei & 5.108 & tercemar sedang & 2.482 & tercemar ringan & 3.302 & tercemar ringan & 2.004 & tercemar ringan \\
\hline Jun & 4.762 & tercemar ringan & 1.825 & tercemar ringan & 2.850 & tercemar ringan & 4.348 & tercemar ringan \\
\hline Jul & 4.317 & tercemar ringan & 2.951 & tercemar ringan & 3.036 & tercemar ringan & & \\
\hline Agt & 4.743 & tercemar ringan & 1.025 & tercemar ringan & 4.276 & tercemar ringan & & \\
\hline Sept & 5.162 & tercemar sedang & 2.238 & tercemar ringan & 2.589 & tercemar ringan & & \\
\hline Okt & 5.246 & tercemar sedang & 2.552 & tercemar ringan & 3.778 & tercemar ringan & & \\
\hline Nov & 4.233 & tercemar ringan & 3.691 & tercemar ringan & 3.991 & tercemar ringan & & \\
\hline Des & 3.685 & tercemar ringan & 2.327 & tercemar ringan & 5.410 & tercemar sedang & & \\
\hline
\end{tabular}

Tabel 3. Rekapitulasi Status Mutu Air Kali Surabaya di Stasiun Monitoring Jagir

\begin{tabular}{ccccccccc} 
Bulan & \multicolumn{2}{c}{$\mathbf{2 0 1 0}$} & $\mathbf{2 0 1 1}$ & $\mathbf{2 0 1 2}$ & $\mathbf{2 0 1 3}$ \\
\cline { 2 - 8 } Jan & 5.855 & Tercemar Sedang & 4.740 & tercemar ringan & 4.083 & Tercemar Ringan & 4.384 & Tercemar Ringan \\
Feb & 5.781 & Tercemar Sedang & 1.861 & tercemar ringan & 4.205 & Tercemar Ringan & 2.824 & Tercemar Ringan \\
Mar & 6.028 & Tercemar Sedang & 2.497 & tercemar ringan & 2.407 & Tercemar Ringan & 3.054 & Tercemar Ringan \\
Apr & 5.859 & Tercemar Sedang & 5.660 & tercemar sedang & 4.756 & Tercemar Ringan & 4.331 & Tercemar Ringan \\
Mei & 5.600 & Tercemar Sedang & 2.482 & tercemar ringan & 3.359 & Tercemar Ringan & 2.347 & Tercemar Ringan \\
Jun & 6.181 & Tercemar Sedang & 1.825 & tercemar ringan & 2.701 & Tercemar Ringan & 2.761 & Tercemar Ringan \\
Jul & 5.110 & Tercemar Sedang & 2.951 & tercemar ringan & 2.234 & Tercemar Ringan & & \\
Agt & 5.229 & Tercemar Sedang & 1.025 & tercemar ringan & 3.457 & Tercemar Ringan & & \\
Sept & 4.920 & Tercemar Ringan & 2.238 & tercemar ringan & 3.130 & Tercemar Ringan & & \\
Okt & 3.494 & Tercemar Ringan & 2.552 & tercemar ringan & 3.743 & Tercemar Ringan & & \\
Nov & 4.428 & Tercemar Ringan & 3.691 & tercemar ringan & 2.970 & Tercemar Ringan & & \\
Des & 3.085 & Tercemar Ringan & 2.327 & tercemar ringan & 5.749 & TercemarSedang & & \\
\hline
\end{tabular}

Diketahui bahwa status mutu air Kali Surabaya di Titik Gunungsari dan Jagir pada tahun 20102013 tergolong tercemar ringan. Kemudian dilakukan uji probabilistik untuk membuktikan bahwa status mutu air Kali Surabaya termasuk tercemar ringan.

Diketahui: Rata-rata $(\bar{x})$ PI gunungsari $=3,55$; $\Sigma\left(\mathrm{x}_{\mathrm{i}}-\bar{x}\right)^{2}=76,49 ; \mathrm{z}_{0,05}=1,645 ; \mu=5$
$\mathrm{H}_{0} \leq 3,55 ; \mathrm{H}_{1}>5$ (jika nilai $\mathrm{PI}>5$ maka tercemar sedang)

Simpangan baku:

$$
\sigma=\sqrt{\left(x_{i}-\bar{x}\right)^{2} / n}=\sqrt{76,49 / 42}=1,35
$$

$Z_{\text {hit }}=\frac{3,55-5}{1,35 / \sqrt{42}}=-0,17<\mathrm{Z}_{0,05} \rightarrow \mathrm{H}_{0}$ diterima 
Sehingga dapat disimpulkan bahwa status mutu air Kali Surabaya tergolong tercemar ringan.Hasil menunjukkan nilai zhit gunung sari adalah -0,17 dan zhit Jagir adalah -0,129. Zhit keduanya tidak melebihi $\mathrm{z}$ table sehingga dapat disimpulkan bahwa status mutu air Kali Surabaya yaitu tercemar ringan.

\section{Strategi Pengendalian Pencemaran}

Strategi pengendalian pencemaran air Kali Surabaya adalah upaya pengurangan pencemar di air sungai. Pada penelitian ini upaya tersebut dapat dilakukan secara maksimal jika dilakukan dari segala aspek. Oleh sebab itu prioritas pengendalian pencemaran ditinjau dari aspek teknis, sosial, kelembagaan, dan lingkungan. Hasil kuesioner yang telah dinormalisasikan kemudian diinputkan pada software sehingga muncul matriks seperti Gambar 3.

Dapat diketahui bahwa prioritas kriteria yang paling tinggi adalah apek sosial $(0,389)$. Sedangkan prioritas alternatif yang terpilih adalah ketegasan dalam rangka menaati peraturan $(0,264)$ dengan nilai inkonsistensi terhadap goal secara keseluruhan 0,03 yang artinya data tersebut valid dan dapat diterima.

Dari running model perbandingan antar aspek, dapat diketahui bahwa aspek sosial lebih berpengaruh $(0,389)$ dari pada aspek lainnya dengan nilai inkonsistensi sebesar 0,01 (1\%) yang artinya data sudah valid. Hal ini membuktikan bahwa aspek sosial harus diperhatikan untuk mengurangi pencemaran air Kali Surabaya. Ditinjau dari aspek teknis, alternatif yang lebih berpengaruh adalah ketegasan dalam upaya menaati peraturan perundangan $(0,249)$ dengan nilai inkonsistensi sebesar 0,06 (6\%) sehingga data yang masuk dapat diterima. Selain itu, peran masyarakat mempunyai bobot sedikit dibawah ketegasan dalam upaya menaati peraturan perundangan dengan nilai 0,237. Hal ini dikarenakan masyarakat juga memegang peranan penting dalam pengendalian pencemaran air Kali Surabaya.

Ditinjau dari aspek sosial, prioritas alternatif yang terpilih adalah ketegasan dalam upaya menaati peraturan perundangan $(0,259)$ dengan nilai inkonsistensi sebesar $0,02(2 \%)$ sehingga data yang masuk dapat diterima.

Ditinjau dari aspek kelembagaan, alternatif yang terpilih berdasarkan kepentingannya adalah ketegasan dalam upaya menaati peraturan perundangan $(0,291)$ dengan nilai inkonsistensi sebesar 0,03 (3\%) sehingga data yang masuk dapat diterima.

Pada aspek lingkungan, alternatif yang lebih penting adalah peran masyarakat $(0,274)$ dengan nilai inkonsistensi 0,05 (5\%) sehingga rekap kuesioner yang diinputkan kedalam model dapat diterima. Secara keseluruhan, alternatif yang terpilih dapat terlihat pada Gambar 4.

Ketegasan dalam upaya menaati peraturan perundangan $(0,259)$ dengan nilai inkonsistensi sebesar 0,03 (3\%) sehingga data yang masuk dapat diterima. Selain itu, peran masyarakat mempunyai bobot sedikit dibawah ketegasan dalam upaya menaati peraturan perundangan dengan nilai 0,226. Hal ini dikarenakan masyarakat juga memegang peranan penting dalam pengendalian pencemaran air Kali Surabaya.

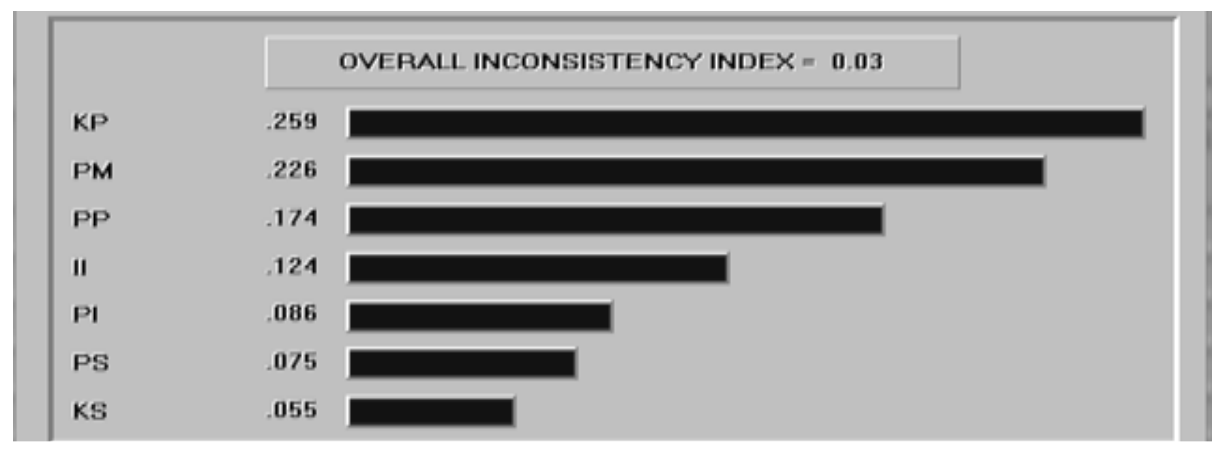

Gambar 4. Hasil Running Alternatif Berdasarkan Goal 


\section{KESIMPULAN}

Kesimpulan yang dapat diperoleh dari penelitian ini antara lain teridentifikasi bahwa parameter pencemar air Kali Surabaya adalah TSS, BOD, DO, Nitrit, Minyak, dan Fenol. Teridentifikasi bahwa status mutu air Kali Surabaya tergolong tercemar ringan. Prioritas strategi pengendalian pencemaran air Kali Surabaya adalah ketegasan dalam rangka menaati peraturan perundangan yang artinya pemberian sanksi terhadap siapa saja pelanggar peraturan yang dalam hal ini siapa saja yang mencemari air sungai.

\section{DAFTAR PUSTAKA}

Bevilacqua dan Braglia .2000. The Analytic Hierarchy Process Applied To Maintenance Strategy Selection. Journal Reliability and System Safety. 71-83.

Fatnasari, H. dan Joni H. 2010. Strategi Pengelolaan Air Limbah Permukiman di Bantaran Kali Surabaya. Prosiding Seminar Nasional Manajemen Teknologi XI. 6 Pebruari .2010. D-5-1.

Herera, A. (2013). Studi Penentuan Daya Tampung Beban Pencemaran Kali Surabaya Dengan Menggunakan Paket Program QUAL2Kw. Universitas Brawijaya.
Hwang, J. dan Syamsudin 2009. The Application of AHP Model to Guide Decision Makers: A Case Study of EBanking Security.

Keputusan Menteri Lingkungan Hidup Nomor 115 2003. Pedoman Status Penentuan Mutu Air. Jakarta.

Kusumawardani, D. 2010. Valuasi Ekonomi Air Bersih di Surabaya. Universitas Gajah Mada.

Peraturan Pemerintah Republik Indonesia Nomor 82 .2001. Pengelolaan Kualitas Air dan Pengendalian Pencemaran Air. Jakarta.

Wang, C. dan Jhen B .2010. Analysis and Evaluation of Taiwan Water Shortage Factors and Solution Strategies. Asian Social Science. Volume 6. 